\title{
PENERAPAN POLA HIDUP SEHAT SEBAGAI PENJAMIN RAGA YANG BERSIH
}

\author{
ARISMAN ${ }^{1} \&$ FELTA $^{2}$ \\ Fakultas Kesehatan Masyarakat \\ Universitas Dayanu Ikhsanuddin
}

\begin{abstract}
Abstrak
The creation of a clean environment is the responsibility of everyone, including the government through policies and the realization of real actions. Furthermore, to grow this responsibility requires a process and also concrete steps. This real process and steps are the focus of our attention.

Provide awareness about the importance of a clean environment to the community, especially to children so that awareness can grow from an early age. Getting used to living clean from a young age is certainly more fruitful than habituation at a later age. The reason, of course, has to do with the awareness that has emerged through habit. Children do not need to be ordered or forced to always keep themselves and their environment clean. They are given an example and an understanding of the importance of cleanliness, then it will stick and be carried out to the maximum and as best as possible in their lives. They will continue to remember well the positive things that they often do with awareness without any fear, worry or anxiety if they have not succeeded in making efforts to maintain cleanliness. They will continue to learn and practice because the surrounding environment provides examples and understanding correctly.
\end{abstract}

\section{PENDAHULUAN}

Pencemaran lingkungan merupakan masalah kita bersama, yang semakin penting untuk diselesaikan, karena menyangkut keselamatan, kesehatan, dan kelangsungan kehidupan kita. Siapapun bisa berperan serta dalam menyelesaikan masalah pencemaran lingkungan ini, termasuk kita. Dimulai dari lingkungan yang terkecil, diri kita sendiri, sampai ke lingkungan yang lebih luas. Sekarang kita sementara dihadapkan dengan kondisi lingkungan yang sangat rumit, yakni munculnya virus yang sangat mematikan. Virus yang dimaksud adalah virus corona.

Tempat pertama kali virus corona ditemukan, yakni di Kota Wuhan, China. Penyebaran virus ini sangat cepat hingga saat ini belum ditemukan vaksin ataupun penawarnya. Adapun korban akibat covid-19 ini sudah mencapai jutaan orang sampai meninggal dunia. Awal bulan Januari 2020, covid-19 sudah menyebar ke negara Indonesia. Pakar Epidemiologi Universitas Indonesia (UI), Pandu Riono, menuturkan 
bahwa tangga 2 Maret 2020 untuk pertama kalinya pemerintah mengumumkan melalui media massa bahwa terdapat dua kasus pasien positif covid19 di Indonesia. Hal ini dipertegas WHO, bahwa data per tanggal 2 Maret 2020 jumlah penderita sebanyak 90.308 terinfeksi covid-19 (Susiati, et. al, 2021).

Menerapkan pola hidup sehat dan bersih merupakan tanggung jawab diri sendiri, keluarga, hingga lingkungan masyarakat. Pembiasaan pola hidup tersebut perlu diterapkan sejak dini terlebih pada masa pandemi Covid-19 sekarang. Membiasakan pola hidup sehat bermaksud memberikan kegiatan pada seseorang tentang hidup sehat dan bersih secara berulang-ulang sehingga menjadi suatu kebiasaan (Wiranata, 2020). Peran orang tua sangatlah penting dan berpengaruh dalam membiasakan pola hidup sehat dan bersih dalam keluarga. Orang tua berkewajiban menentukan pilihan layanan kesehatan yang berkualitas bagi anggota keluarga, termasuk jenis makanan yang dimakan, dukungan emosional, kegiatan hidup sehari-hari (aktivitas fisik), serta kualitas lingkungan (Inderan dan Weta, 2018). Oleh karena itu, membiasakan pola hidup sehat dan bersih kepada anggota keluarga khususnya dan masyarakat di masa pandemi Covid-19 ini dapat berupa edukasi dengan metode praktik, secara langsung maupun melalui media pamflet bergambar kartun. Jika masyarakat membiasakan diri berpola hidup sehat dan bersih sejak sekarang, maka secara tidak langsung masyarakat telah berperan aktif dalam memerangi keberadaan Covid-19 di Indonesia (Susiati, et. al, 2021)

Permasalahan pencemaran lingkungan yang harus segera kita atasi bersama diantaranya pencemaran air tanah dan sungai, pencemaran udara perkotaan, kontaminasi tanah oleh sampah, hujan asam, perubahan iklim global, penipisan lapisan ozon, kontaminasi zat radioaktif, dan sebagainya.

Untuk menyelesaikan masalah pencemaran lingkungan ini, tentunya kita harus mengetahui sumber pencemar, bagaimana proses pencemaran itu terjadi, dan bagaimana langkah penyelesaian pencemaran lingkungan itu sendiri. Tujuan Penulisan makalah ini, yakni Mengetahui Apa Yang dimaksud dengan Lingkuang Hidup, Mengetahui Bagaimana Cara Menciptakan Lingkungan yang bersih dan Sehat, Mengetahui apa Manfaat dari Lingkungan Yang bersih dan Sehat.

\section{PEMBAHASAN}

\section{Definisi Lingkungan Hidup}

Sebelum kita membahas tentang pencemaran lingkungan, ada baiknya kita harus mengetahui terlebih dahulu definisi dari lingkungan itu sendiri. Dalam makalah ini akan disampaikan beberapa defisini tentang lingkungan. 
Menurut Undang Undang No. 23 Tahun 1997, lingkungan hidup adalah kesatuan ruang dengan semua benda, daya, keadaan, dan makhluk hidup, termasuk manusia dan perilakunya, yang mempengaruhi kelangsungan perikehidupan dan kesejahteraan manusia serta makhluk hidup lain. Sedangkan ruang lingkup lingkungan hidup Indonesia meliputi ruang, tempat Negara Kesatuan Republik Indonesia yang berWawasan Nusantara dalam melaksanakan kedaulatan, hak berdaulat, dan yurisdiksinya.

Secara hukum maka wawasan dalam menyelenggarakan penegakan hukumpengelolaan lingkungan hidup di Indonesia adalah Wawasan Nusantara. Sedangkan pengertian dan definisi lingkungan hidup menurut para ahli:

Lingkungan hidup adalah Semua benda dan kondisi yang terdapat di dalam ruang dimana manusia itu berada dan berpengaruh terhadap kelangsungan dan kesejahteraan manusia (Munajat saputra).

Lingkungan hidup adalah Lingkungan adalah jumlah sebuah benda dan kondisi yang berada di dalam ruang yang kita tempati yang mempengaruhi Kehidupan manusia (Otto Sumarwoto).

Lingkungan hidup adalah Segala benda, kondisi, keadaan dan pengaruhnya yang terdapat di dalam ruang yang mempengaruhi segala yang berada di dalam ruang yang kita tempati (Emil Salim).

Lingkungan hidup adalah jumlah semua benda dan kondisi yang ada dalam ruang yang kita tempati yang mempengaruhi kehidupan kita (PROF DR. IR. OTTO SOEMARWOTO).

Lingkungan hidup adalah semua faktor ekstrenal yang bersifat biologis dan fisika yang langsung mempengarui kehidupan, pertumbuhan, perkembangan dan reproduksi organisme (S.J MCNAUGHTON \& LARRY L. WOLF).

Lingkungan hidup diartikan sebagai: the physical, chemical and biotic condition surrounding and organism (MICHAEL ALLABY).

Lingkungan hidup sebagai semua benda dan kondisi, termasuk di dalamnya manusia dan tingkah perbuatannya, yang terdapat dalam ruang tempat manusia berada dan mempengaruhi hidup serta kesejahteraan manusia dan jasad hidup lainnya (PROF. DR. ST. MUNADJAT DANUSAPUTRO, SH).

Lingkungan hidup adalah kesatuan ruang dengan semua benda dan keadaan mahluk hidup. termasuk di dalamnya manusia dan perilakunya yang melangsungkan perikehidupan dan kesejahteraan manusia serta mahluk hidup lainnya (SRI HAYATI).

Lingkungan hidup adalah wilayah yang merupakan tempat berlangsungnya bermacam-macam interaksi sosial antara berbagai kelompok beserta pranatanya dengan simbol dan nilai (JONNY PURBA). 
Dalam lingkungan hidup terdapat ekosistem, yaitu tatanan unsur lingkungan hidup yang merupakan kesatuan utuh menyeluruh dan saling mempengaruhi dalam membentuk keseimbangan, stabilitas, dan produktivitas lingkungan hidup.

Merujuk pada definisi di atas, maka lingkungan hidup Indonesia tidak lain merupakan Wawasan Nusantara, yang menempati posisi silang antara dua benua dan dua samudera dengan iklim tropis dan cuaca serta musim yang memberikan kondisi alamiah dan kedudukan dengan peranan strategis yang tinggi nilainya, tempat bangsaIndonesia menyelenggarakan kehidupan bernegara dalam segala aspeknya.

\section{Lingkungan Yang Bersih dan Sehat}

a. Menciptakan Lingkungan yang Bersih dan Sehat

Linkungan bersih merupakan dambaan semua orang. Namun tidak mudah untuk menciptakan lingkungan kita bisa terlihat bersih dan rapi sehingga nyaman untuk dilihat. Tidak jarang karena kesibukan dan berbagai alasan lain, kita kurang memperhatikan masalah kebersihan lingkungan di sekitar kita, terutama lingkungan rumah.

Seiring majunya tingkat pemikiran masyarakat serta kemajuan teknologi di segala bidang kehidupan, maka tingkat kesadaran untuk memiliki lingkungan dengan kondisi bersih seharusnya ditingkatkan dari sebelumnya. Beragam informasi mengenai pentingnya lingkungan dengan kondisi bersih serta sehat dapat diketahui melalui media cetak dan online.

Tentu saja lingkungan dalam kondisi bersih serta sehat akan membuat para penghuninya nyaman dan kesehatan tubuhnya terjaga dengan baik. Kesehatan tubuh manusia berada pada posisi paling vital. Alasannya tentulah mengarah pada keberagaman kegiatan hidup manusia dalam memenuhi kebutuhan hidupnya. b. Manfaat Lingkungan Yang Bersih dan Sehat

Padahal, ada banyak manfaat yang bisa dirasakan seseorang dengan menjaga lingkungan mereka tetap terlihat bersih dan rapi. Lingkungan yang bersih akan menjauhkan sumber-sumber penyakit untuk berkembang di sekitar kita. Hal itu tentu berkaitan dengan kesehatan. Selain itu, dengan lingkungan yang bersih pula, kita akan merasa nyaman dan betah untuk berada di rumah.

Sebenarnya bukan hanya terbatas pada lingkungan rumah, tapi juga lingkungan sekitar tempatnya berada. Rumah memang menjadi bagian paling dekat dari kehidupan manusia. Segala rencana serta persiapan hidup untuk masa depan, senantiasa direncanakan di rumah secara persentase yang besar oleh manusia di dunia ini.

Jadi, sudah selayaknya menjaga kebersihan serta kesehatan lingkungan rumah menjadi tanggungjawab masing-masing individu. Meski faktor lain di luar lingkungan 
rumah juga mempengaruhi kondisi kebersihan maupun kesehatan tubuh, tapi lingkungan rumah termasuk paling inti dan pertama harus dijaga lebih dulu.

Lingkungan dengan kondisi bersih yang bebas dari timbunan sampah,juga akan terhindar dari bencana seperti banjir pada musim hujan. Salah satu penyebab banjir di berbagai wilayah adalah karena banyaknya sampah yang berserakan sehingga menghambat aliran air. Hal ini merupakan salah satu perilaku buruk seakan sudah menjadi budaya masyarakat Indonesia, khususnya di wilayah perkotaan.

Oleh karena itu, menjadikan sampah dalam kondisi berserakan bahkan tertimbun tidak baik. Upaya untuk menanggulangi sampah seperti dibersihkan ataupun di daur ulang bagi bahan yang dapat didaur ulang, maka hal itu dapat dicoba untuk dilakukan secara kon?nyu.

Upaya yang lain pun dapat dilakukan, tentu dengan kerjasama yang baik antara semua pihak. Bukan hanya terbatas pada individu tapi juga pada masyarakat serta ketegasan pemerintah diikuti kepedulian yang tinggi terhadap masalah sampah. Sebenarnya hal yang menjadikan lingkungan kotor bukan hanya terbatas pada sampah, ada hal lainnya juga.

Ada kemungkinan pengaruh penggunaan bahan-bahan untuk kebutuhan hidup dari bahan sintesis ataupun kimiawi dan sebagainya. Hal itu dapat diupayakan penanggulangannya dengan mengajak seluruh lapisan masyarakat tanpa terkecuali dia pejabat pemerintah ataukah tidak, semua dimunculkan kesadarannya untuk hidup sehat dan bersih.

c. Budaya Hidup Bersih dan Sehat

Budaya membuang sampah di sungai dan selokan, menyebabkan lingkungan yang bersih sulit dicapai. Namun, untuk mengubah kebiasaan tersebut pun bukan hal yang mudah dilakukan. Keterbatasan lahan untuk membuat tempat sampah, menjadi alasan masyarakat kota untuk membuang sampah secara sembarangan

Karena itulah, wajarjika upaya melalui budaya hidup bersih dan sehat belum juga maksimal dilakukan secara serentak di seluruh wilayah. Karenanya, kerjasama pemerintah dengan masyarakat harus terjalin dengan baik agar tempat pembuangan sampah serta upaya memunculkan kesadaran hidup bersih dan sehat terealisasi secara maksimal.

Pemerintah tidak dapat hanya sebatas menghimbau mengenai kebersihan lingkungan itu penting. Tapi, peran pemerintah lebih dari itu. Mulai dari memberikan contoh, langsung terjun ke lingkungan masyarakat melalui sosialisasi hidup bersih dan tindakan nyata penyediaan area pembuangan sampah, aturan tentang kebersihan dan sebagainya.

Melalui kerjasama yang baik dan saling mendukung, tentu upaya memunculkan kesadaran budaya hidup sehat dan bersih akan tampak ringnan dan mudah diwujudkan 
dalam waktu singkat. Pengaruh kehidupan di lingkungan masyarakat dengan kebersihan yang terjaga pun akan dapat segera dirasakan secara langsung.

Selain itu, ulasan ini pun juga akan membantu memberikan gambaran mengenai beberapa langkah untuk menciptakan lingkungan dengan kebersihan yang terjaga. Cara ini termasuk cara yang mudah untuk dilakukan secara bersama antara individu, masyarakat hingga pemerintah.

d. Cara Menciptakan Lingkungan Bersih dan Sehat

Penciptaan lingkungan yang bersih adalah tanggungjawab semua orang termasuk di dalamnya pemerintah melalui kebijakan dan realisasi tindakan nyatanya. Selanjutnya untuk menumbuhkan tanggung jawab tersebut dibutuhkan proses dan juga langkah nyata. Proses dan langkah nyata inilah yang menjadi focus perhatian kita.

Kedua hal tersebut harus dilakukan secara beriringan sehingga tujuan menciptakan lingkungan dalam kondisi kebersihan terjaga bisa tercapai tanpa ada paksaan. Selain itu, tujuan itu juga merupakan sebuah kesadaran dan kebutuhan semua orang. Ada beberapa langkah yang harus dilakukan untuk menciptakan lingkungan yang bersih. Langkah-langkah tersebut di antaranya adalah:

Memberikan kesadaran tentang arti penting lingkungan yang bersih kepada masyarakat, terutama pada anak-anak agar kesadaran tersebut bisa tumbuh sejak usia dini. Membiasakan hidup bersih sejak usia anak-anak tentu lebih membuahkan hasil yang luar biasa daripada pembiasaan diri pada usia setelahnya. Alasannya tentu saja berkaitan dengan kesadaran yang berhasil muncul melalui kebiasaan. Anak-anak tidak perlu diperintah ataupun dipaksa untuk senantiasa menjaga kebersihan diri dan lingkungannya. Mereka diberi contoh dan pemahaman akan pentingnya kebersihan, maka hal itu akan menancap dan dilakukan dengan maksimal dan sebaik mungkin dalam kehidupannya. Mereka akan terus mengingat dengan baik hal positif yang sering dilakukannya dengan kesadaran tanpa adanya rasa takut, khawatir ataupun was-was jika belum berhasil melakukan upaya menjaga kebersihan. Mereka akan terus belajar dan berlatih karena lingkungan sekitarnya memberikan contoh dan pemahaman dengan benar.

Buatlah tempat sampah yang memisahkan antara sampah organik dan non organik. Hal ini penting dilakukan agar memudahkan upaya untuk menanggulangi timbunan sampah. .Jika sampah organik berhasil dipisahkan, maka akan mudah untuk merencanakan langkah positif terhadap sampah. Sampah adalah komponen yang begitu dekat dengan kehidupan manusia. Dan seringkali dalam pembuangannya menimbulkan banyak permasalahan. Untuk itu, haruslah dipikirkan cara yang paling tepat untuk dapat mengelola sampah ini termasuk dalam pembuangan mulai dari tahap di rumah tangga 
sampai di tempat pembuangan terkahir. Atau juga bagaimana cara untuk mendaur ulang sampah agar masih dapat untuk dipergunakan kembali.

Buatlah jadwal rutin untuk melakuan aktivitas pembersihan lingkungan secara terjadwal. Melalui jadwal, maka kita akan membiasakan diri disiplin menjaga kebersihan lingkungan. Tidak masalah meski ada kendala di tengah pelaksanaannya. Tapi hal penting adalah keseriusan dan keberlanjutan hidup bersih serta sehat Kita tak akan mendapatkan atau merasakan manfaat dari lingkungan yang bersih tanpa adanya kemauan dari diri kita sendiri untuk melakukan pembersihan lingkungan. Dan hal ini seharusnya dijadikan sebagai sebuah kebiasaan hidup. Bukan lagi sebagai hal yang hanya dilakukan sesekali namun haruslah dijadwal atau diagendakan secara rutin.

Buatlah sebuah aktivitas kreatif untuk mengelola sampah non organik menjadi sebuah benda yang bersifat produktif dan bisa menghasilkan uang. Hal ini dapat diketahui beragam informasinya melalui beragam media, baik cetak maupun online. Sejatinya saat ini telah banyak ditemukan ide kreatif untuk mengelola kembali sampah menjadi barang yang lebih berguna. Kita dapat mencontoh ide yang sudah ada atau memikirkan ide lain yang berbeda. Poin yang terpenting adalah bahwa sampah tersebut dapat untuk kembali diolah tanpa memberikan beban yang lebih bagi alam dan lingkungan.

Biasakan untuk membuang sampah pada tempatnya. Hal ini akan sangat bermanfaatjika diberikan juga kepada anak-anak, sehingga akan menjadi sebuah pola perilaku yang tercipta di bawah sadar. Seperti yang telah disebutkan bahwa masalah sampah adalah masalah yang klasik. Namun dapat dipercahkan dengan banyak hal yang sederhana. Dengan membiasakan untuk membuang sampah ke tempat sampah yang benar adalah hal awal untuk menanggulangi masalah sampah ini.

ltulah beberapa cara yang dapat dilakukan untuk menciptakan lingkungan bersih di sekitar kita. Dengan lingkungan yang bersih maka akan banyak manfaat yang akan dirasakan oleh hidup kita.

\section{Pengertian Kesehatan Lingkungan}

Kesehatan lingkungan adalah kesehatan yang sangat penting bagi kelancaran kehidupan dibumi, karena lingkungan adalah tempat dimana pribadi itu tinggal. Lingkungan yang sehat dapat dikatakan sehat bila sudah memenuhi syarat-syarat lingkungan yang sehat.

Kesehatan lingkungnan yaitu bagian integral ilmu kesehatan masyarakat yang khusus menangani dan mempelajari hubungan manusia dengan lingkungan dalam keseimbangan ekologis.

Jadi kesehatan lingkungan merupakan bagian dari ilmu kesehatan mayarakat. 


\section{Syarat-syarat Lingkungan Yang Sehat}

\section{a. Keadaan Air}

Air yang sehat adalah air yang tidak berbau, tidak tercemar dan dapat dilihat kejernihan air tersebut, kalau sudah pasti kebersihannya dimasak dengan suhu 1000C, sehingga bakteri yang di dalam air tersebut mati.

\section{b. Keadaan Udara}

Udara yang sehat adalah udara yang didalamnya terdapat yang diperlukan, contohnya oksigen dan di dalamnya tidka tercear oleh zat-zat yang merusak tubuh, contohnya zat $\mathrm{CO} 2$ (zat carbondioksida).

c. Keadaan tanah

Tanah yang sehat adalah tamah yamh baik untuk penanaman suatu tumbuhan, dan tidak tercemar oleh zat-zat logam berat.

\section{PENUTUP}

Penciptaan lingkungan yang bersih adalah tanggungjawab semua orang termasuk di dalamnya pemerintah melalui kebijakan dan realisasi tindakan nyatanya. Selanjutnya untuk menumbuhkan tanggung jawab tersebut dibutuhkan proses dan juga langkah nyata. Proses dan langkah nyata inilah yang menjadi focus perhatian kita.

Kedua hal tersebut harus dilakukan secara beriringan sehingga tujuan menciptakan lingkungan dalam kondisi kebersihan terjaga bisa tercapai tanpa ada paksaan. Selain itu, tujuan itu juga merupakan sebuah kesadaran dan kebutuhan semua orang. Ada beberapa langkah yang harus dilakukan untuk menciptakan lingkungan yang bersih. Langkah-langkah tersebut di antaranya adalah:

Memberikan kesadaran tentang arti penting lingkungan yang bersih kepada masyarakat, terutama pada anak-anak agar kesadaran tersebut bisa tumbuh sejak usia dini. Membiasakan hidup bersih sejak usia anak-anak tentu lebih membuahkan hasil yang luar biasa daripada pembiasaan diri pada usia setelahnya. Alasannya tentu saja berkaitan dengan kesadaran yang berhasil muncul melalui kebiasaan. Anak-anak tidak perlu diperintah ataupun dipaksa untuk senantiasa menjaga kebersihan diri dan lingkungannya. Mereka diberi contoh dan pemahaman akan pentingnya kebersihan, maka hal itu akan menancap dan dilakukan dengan maksimal dan sebaik mungkin dalam kehidupannya. Mereka akan terus mengingat dengan baik hal positif yang sering dilakukannya dengan kesadaran tanpa adanya rasa takut, khawatir ataupun was-was jika belum berhasil melakukan upaya menjaga kebersihan. Mereka akan terus belajar dan berlatih karena lingkungan sekitarnya memberikan contoh dan pemahaman dengan benar. 
Kesehatan lingkungnan yaitu bagian integral ilmu kesehatan masyarakat yang khusus menangani dan mempelajari hubungan manusia dengan lingkungan dalam keseimbangan ekologis.

\section{DAFTAR PUSTAKA}

Soemirat, Juli . 2011. Kesehatan Lingkungan . Penerbit Gadjah Mada University Press . Jakarta

http://dzumanjipunya.wordpress.com/2012/01/02/kesehatan-lingkungan/ 29-112012 / 17.20

Susiati, S., Makatita, S. H., Azwan, A., Taufik, T., Musyawir, M., Amir, N. F., \& Indrayani, N. (2021). Edukasi Pola Hidup Sehat dalam Menghadapi Tanggap Darurat Pandemi Covid-19. Jurnal Abdidas, 2(2), 287-296.

Susiati, S., Tahir, S. Z. B., Hajar, I., \& Tenriawali, A. Y. (2021). Optimalisasi Masyarakat Desa Namlea Dalam Menghadapi Tanggap Darurat Pandemi Covid-19. Journal of Community Dedication and Development (Pengabdian Kepada Masyarakat), 1(1), 50-59. 